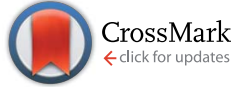

Cite this: Med. Chem. Commun., 2014, 5,1651

Received 18th April 2014

Accepted 30th July 2014

DOI: $10.1039 / c 4 m d 00177 j$

www.rsc.org/medchemcomm

\title{
Modeling, synthesis and NMR characterization of novel chimera compounds targeting STAT3†
}

\author{
Silvia Dell'Orto, ${ }^{a}$ Daniela Masciocchi, ${ }^{\text {a }}$ Stefania Villa, ${ }^{a}$ Fiorella Meneghetti, ${ }^{a}$ \\ Giuseppe Celentano, ${ }^{a}$ Daniela Barlocco, ${ }^{a}$ Diego Colombo, ${ }^{b}$ Laura Legnani, ${ }^{\text {bc }}$ \\ Lucio Toma, ${ }^{c}$ Yoon Jung Jeon, ${ }^{d}$ Byoung-Mog Kwon, ${ }^{d}$ Akira Asai ${ }^{e}$ \\ and Arianna Gelain*a
}

Signal Transducer and Activator of Transcription 3 (STAT3) is a cytoplasmic factor that mediates intracellular signaling commonly generated at cell surface receptors and transmits it to the nucleus. In previous research studies we synthesized several molecules inhibiting STAT3 and among them oxadiazole MD77 and pyridazinone I showed an interesting activity. For the first one, a direct inhibition mechanism was determined, while I interfered within the STAT3 pathway at a different level. In order to discover novel compounds possibly endowed with an improved activity, we decided to merge their scaffolds on the basis of their calculated conformational properties. Therefore we designed and synthesized the chimera diastereomers 3-oxo-N-(4-(trifluoromethyl)phenyl)-2,3,4,4a,5,6-hexahydrobenzo[h]cinnoline-6carboxamide $(1,2)$ and 3-oxo- $N$-(4-(trifluoromethyl)phenyl)-2,3,5,6-tetrahydrobenzo[h]cinnoline-6carboxamide (3) as racemate and their enantiomeric separation was performed. Modeling studies and theoretical prediction of $[\alpha]_{D}$ values were carried out beside NMR studies which allowed us to assign 1 and 2 relative configurations.

\section{Introduction}

STATs (Signal Transducers and Activators of Transcription) are latent cytoplasmic proteins transducing signals through the cytoplasm and acting as transcription factors in the nucleus, regulating cell growth and survival. ${ }^{1}$ They are constituted by several structurally and functionally conserved domains: among them, the Src homology 2 ( $\mathrm{SH} 2$ ) domain is essential for the STAT activation cascade. STAT3, a member of the STAT family, has been found constitutively activated in a wide variety of human solid and blood tumors and the suppression of deregulated STAT3 activation leads to cancer cell apoptosis with tumor regression, slightly affecting normal cells. ${ }^{2}$

${ }^{a}$ Dipartimento di Scienze Farmaceutiche, Università degli Studi di Milano, Via L. Mangiagalli 25, 20133 Milano, Italy. E-mail: arianna.gelain@unimi.it; Fax: +39-02503-19359; Tel: +39-02-503-19369

${ }^{b}$ Dipartimento di Biotecnologie Mediche e Medicina Traslazionale, Università degli Studi di Milano, Via Saldini 50, 20133 Milano, Italy

'Dipartimento di Chimica, Università degli Studi di Pavia, Via Taramelli 12, 27100 Pavia, Italy. Fax: +39-0382-98-7323; Tel: +39-0382-98-7311

${ }^{d}$ Laboratory of Chemical Biology and Genomics, Korea Research Institute of Bioscience $\&$ Biotechnology and Department of Biomolecular Science, Korea University of Science and Technology, Eoun-Dong, Yuseong-gu, DaeJeon 305-333, South Korea

${ }^{e}$ Center for Drug Discovery, Graduate School of Pharmaceutical Sciences, University of Shizuoka, 52-1 Yada, Suruga-ku, Shizuoka, 422-8526, Japan

$\dagger$ Electronic supplementary information (ESI) available. See DOI: $10.1039 / \mathrm{c} 4 \mathrm{md} 00177 \mathrm{j}$
In previous research studies focused on the discovery of new inhibitors targeting aberrant STAT3 signaling, we described the oxadiazole MD77, ${ }^{3}$ a direct STAT3 $\mathrm{SH} 2$ domain inhibitor $\left(\mathrm{IC}_{50}\right.$ value $17.7 \mu \mathrm{M}$, by Alpha-Screen based assay) and the pyridazinone $\mathbf{I}^{4}$ exhibiting good inhibitory activity (46\% STAT3 inhibition at $2 \mu \mathrm{M}$ concentration, by dual luciferase assay), but unable to bind the SH2 domain (Chart 1).

Docking studies performed on MD77 showed that, in the best scored pose of the STAT3-MD77 complex, it maintained the same geometry shown to be preferred in water solution, established by molecular modeling calculations, and characterized by torsional angles $\tau_{1}-\tau_{4}$ more or less deviated from planarity. ${ }^{3}$ In this pose MD77 showed a series of interactions with suitable functional groups in the SH2 domain involving its various molecular portions, among which the $p$-trifluoromethylphenyl moiety

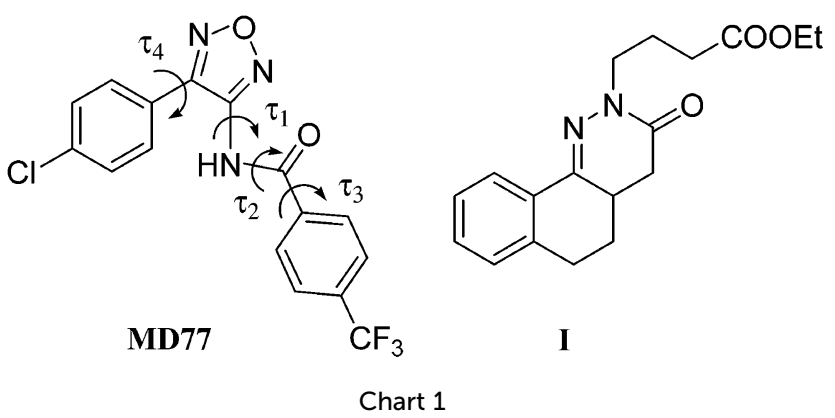


<smiles>O=C1C[C@@H]2CC(C(=O)Nc3ccc(C(F)(F)F)cc3)c3ccccc3C2=NN1</smiles><smiles>O=C(Nc1ccc(C(F)(F)F)cc1)C1Cc2cc(=O)[nH]nc2-c2ccccc21</smiles>

1a: $(6 R, 4 \mathrm{a} S)$

3a: $(6 R)$

1b: $(6 S, 4 \mathrm{a} R)$

3b: $(6 S)$

2a: $(6 R, 4 \mathrm{a} R)$

2b: $(6 S, 4 \mathrm{a} S)$

Chart 2

engaged in several hydrogen bonds. As far as pyridazinone $\mathbf{I}$ is concerned, an important requisite for inhibitory activity versus STAT3 seems to be the planar or almost planar arrangement of the polycyclic system, that presents only one geometry significantly populated, in complete agreement with that described in a previous paper and obtained with a molecular mechanics approach. ${ }^{5}$

The main degree of conformational freedom in $\mathbf{I}$ is represented by the N2 side chain, able to assume two almost isoenergetic orientations, that, however, does not seem to exert a significant effect on the activity.

Taking into account the biological results of these previously studied molecules, and their geometrical features determined by molecular modeling calculations, we have chemically merged their scaffolds aided by molecular modeling calculations in order to identify new molecules endowed with enhanced activity against STAT3. Their synthesis was planned to verify if the MD77 $p$-trifluoromethylphenyl moiety, which plays a crucial role for the binding to the target, could address the pyridazinone nucleus in proximity of the dimerization interface. This approach started from the above stated consideration concerning the almost planar conformation of the tricyclic moiety. Therefore, the chimeras 1-3 (Chart 2) were designed introducing on the central ring of $\mathbf{I}$ the $p$-trifluoromethylphenyl moiety of MD77 in a position able to maintain its original orientation within the protein binding pocket.

Here we report the synthesis of $\mathbf{1 - 3}$, the complete exploration of their conformational space performed through theoretical calculations, the racemate separations, the NMR characterization as well as the results of the biological assays.

\section{Chemistry}

Starting from the commercially available $\alpha$-phenylglutaric anhydride, by treatment with polyphosphoric acid, the racemic acid 4 was obtained (Scheme 1). The carboxylic group of 4 was
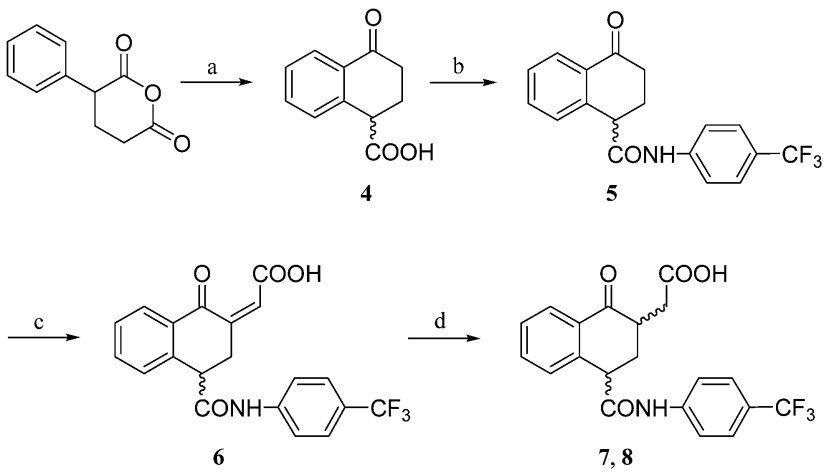

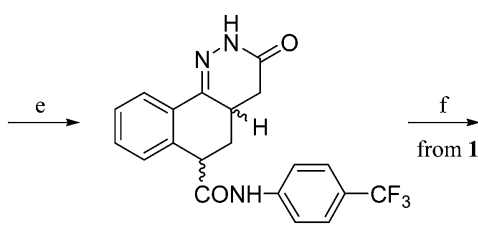

1,2

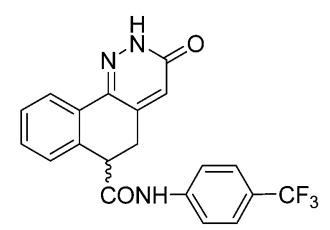

3
Scheme 1 Reagents and conditions: (a) PPA, 100/110 ${ }^{\circ} \mathrm{C}, 30 \mathrm{~min}$; (b) 4-(trifluoromethyl)aniline, $\mathrm{CH}_{2} \mathrm{Cl}_{2}$, TBTU, $\mathrm{N}$-methlymorphine upto $\mathrm{pH}=7, \mathrm{rt}, 24 \mathrm{~h}$; (c) $\mathrm{CHO}-\mathrm{COOH}, \mathrm{NaOH}, \mathrm{H}_{2} \mathrm{O}, \mathrm{EtOH}, \mathrm{rt}, 1 \mathrm{~h}$; (d) $\mathrm{Zn}$, $\mathrm{CH}_{3} \mathrm{COOH}, \mathrm{H}_{2} \mathrm{O}$, rt, 20 min; (e) $\mathrm{NH}_{2} \mathrm{NH}_{2} \cdot \mathrm{H}_{2} \mathrm{O}$, EtOH, reflux, $2 \mathrm{~h}$; (f) Sodium 3-nitrobenzenesulfonate, $\mathrm{NaOH}, \mathrm{H}_{2} \mathrm{O}$, reflux, $30 \mathrm{~min}$.

condensed with 4-(trifluoromethyl)aniline, in the presence of the coupling agent TBTU (O-(benzotriazol-1-yl)- $N, N, N^{\prime}, N^{\prime}$-tetramethyluronium tetrafluoborate), to obtain the amide 5. Aldol condensation between 5 and glyoxylic acid, followed by dehydration, led to the $\alpha, \beta$-unsaturated acid $\mathbf{6}$.

Reduction of the double bond by zinc in acetic acid gave a mixture of the two diastereoisomers 7 and $\mathbf{8}$, which were not separated and directly cyclized with hydrazine monohydrate to give the diastereoisomers $\mathbf{1}$ and $\mathbf{2}$ which were separated by flash chromatography. Dehydrogenation of the dihydropyridazinonic ring of 1 was carried out with sodium 3-nitrobenzenesulfonate to give 3 while 2 did not react under the same conditions. The relative configurations of $\mathbf{1}$ and $\mathbf{2}$ were assigned by means of NOESY experiments.

Finally, in order to perform the biological evaluation of the single enantiomeric entities, we separated the racemates $\mathbf{1}, 2$ and 3 by means of a chiral semi-preparative HPLC.

\section{Computational studies}

The modeling studies on the diastereoisomers 1 and 2, and on compound 3 were carried out with the Gaussian09 program package using the B3LYP exchange-correlation functional at the $6-311+G(d, p)$ level. ${ }^{6}$ The studies were performed on the stereoisomers 1a, 2a and 3a. The discussion is referred to them but it also applies to their enantiomers $\mathbf{1 b}, \mathbf{2} \mathbf{b}$ and $\mathbf{3} \mathbf{b}$, whose conformers are mirror images of those of 1a-3a. The degrees of conformational freedom were considered, namely inversion of the central hexacyclic ring and rotation along the single bond connecting the amide carbonyl group to this ring, with energy minimization and optimization of all the possible starting 
geometries. After the optimization in vacuo, a further optimization was performed at the same level as above using a polarizable continuum solvent model (PCM), choosing chloroform, dimethyl sulfoxide, or methanol as the solvent, for 1a, 2a and 3a, respectively. Fig. 1 shows the minimum energy conformations of each compound together with the corresponding relative energy and the percentage contribution to the overall population at $298 \mathrm{~K}$. A very different conformational behaviour was found between the two diastereoisomers 1a and 2a. In fact, whereas in 1a the trifluoromethylphenylamido chain almost exclusively (99.9\%) prefers the pseudo-axial orientation, in its diastereoisomer $\mathbf{2 a}$ the opposite pseudo-equatorial orientation is largely preferred (96.2\%). Compound 3a closely

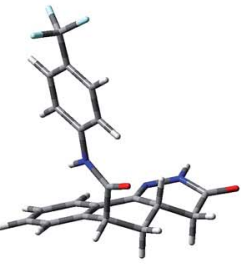

1a-A $0.00,90.0 \%$

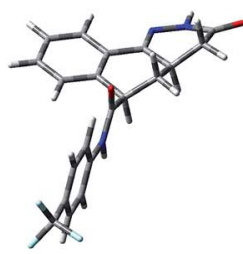

2a-A $0.00,77.5 \%$

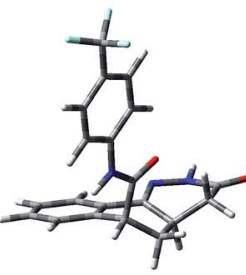

2a-D $2.38,1.4 \%$

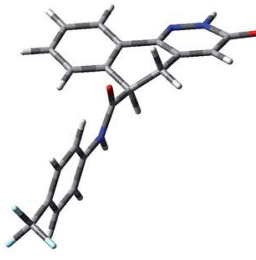

3a-C

$1.07,9.7 \%$

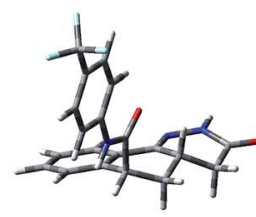

1a-B

$1.31,9.9 \%$

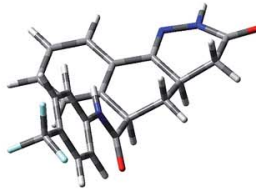

2a-B

$0.84,18.7 \%$

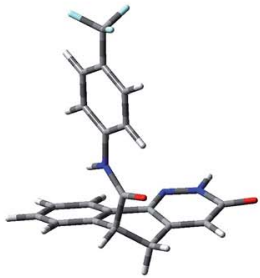

3a-A

$0.00,59.4 \%$

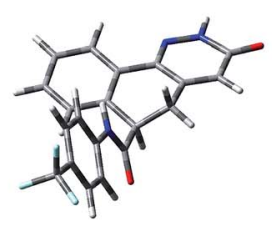

3a-D

$2.46,0.9 \%$

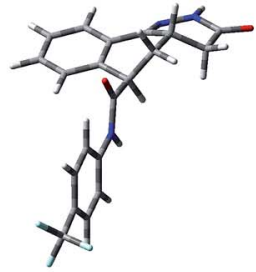

1a-C $4.21,0.1 \%$

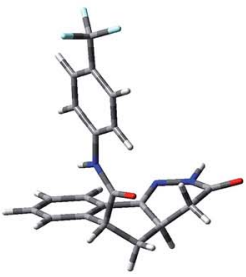

2a-C $2.07,2.4 \%$

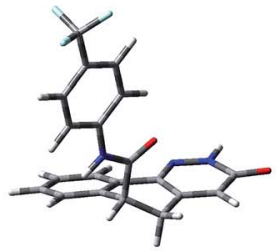

3a-B

$0.42,29.5 \%$

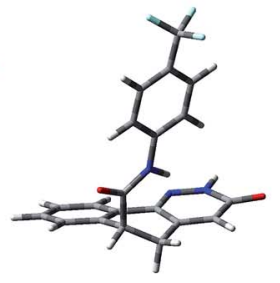

3a-E

$2.78,0.5 \%$
Fig. 1 Three-dimensional plots of the populated conformers of compounds $1 \mathrm{a}(1 \mathrm{a}-\mathrm{A}, \mathrm{B}, \mathrm{C}), 2 \mathrm{a}(2 \mathrm{a}-\mathrm{A}, \mathrm{B}, \mathrm{C}, \mathrm{D})$ and $3 \mathrm{a}(3 \mathrm{a}-\mathrm{A}, \mathrm{B}, \mathrm{C}, \mathrm{D}, \mathrm{E})$ with their relative energy $\left(\mathrm{kcal} \mathrm{mol}^{-1}\right)$ and population percentages. resembles 1a in the preference for the pseudo-axial orientation, though in a lesser percentage $(89.4 \%)$.

Then, in an attempt to suggest the absolute configuration of these compounds, the specific optical rotation of each conformer of compounds 1a-3a was predicted using DFT calculations at the same level as above. ${ }^{7}$ The calculated $[\alpha]_{\mathrm{D}}$ for each conformer was weighted averaged on the basis of its percentage contribution to the overall population and yielded a positive value for $2 \mathbf{a}$ as well as for $3 \mathbf{a}\left([\alpha]_{\mathrm{D}}=+375\right.$ and +387 , respectively) whereas the value obtained for $\mathbf{1 a}$ was too low for a reliable prediction. The largely positive values predicted for $\mathbf{2 a}$ and 3a, compared with the largely positive rotation values of the first eluted enantiomer of 2 and the second eluted enantiomer of 3 (see Experimental), allows us to suggest that the former has the $(6 R, 4 \mathrm{a} R)$ configuration and the latter the $(6 R)$ configuration whereas no prediction seems possible for the enantiomers of 1.

\section{${ }^{1} \mathrm{H}-\mathrm{NMR}$ studies}

Racemic compounds 1, 2 and 3 were submitted to high field NMR spectroscopy (see Experimental) in order to get experimental data on their 3D structure. In particular for each compound ${ }^{1} \mathrm{H}$ resonances were assigned and coupling constants measured. They are reported in Tables 1 and 2 together with the theoretical chemical shifts and coupling constants calculated for each

Table 1 Experimental and calculated selected ${ }^{1} \mathrm{H}$ NMR chemical shifts (ppm) of compounds 1, 2 and 3

\begin{tabular}{lllllll}
\hline $\mathrm{H}$ & 1 Exp. $^{a}$ & 1 Calcd & 2 Exp. & 2 Calcd & 3 Exp. & 3 Calcd \\
\hline 6 & 3.99 & 3.83 & 3.97 & 3.52 & 4.09 & 3.56 \\
$5 \mathrm{ax}^{d}$ & 1.89 & 1.71 & 1.95 & 2.07 & 3.20 & 2.93 \\
$5 \mathrm{eq}^{d}$ & 2.84 & 2.85 & 2.29 & 2.08 & 3.26 & 3.47 \\
$4 \mathrm{a}$ & 3.01 & 2.80 & 2.98 & 2.69 & - & - \\
4 & - & - & - & - & 6.83 & 6.78 \\
$4 \mathrm{ax}^{d}$ & 2.23 & 2.00 & 2.36 & 2.16 & - & - \\
$4 \mathrm{eq}^{d}$ & 2.71 & 2.47 & 2.52 & 2.47 & - & -
\end{tabular}

${ }^{a} \mathrm{CDCl}_{3}, 298 \mathrm{~K} .{ }^{b}$ DMSO- $d_{6}, 308 \mathrm{~K} .{ }^{c} \mathrm{CD}_{3} \mathrm{OD}, 298 \mathrm{~K} .{ }^{d}$ The indexes ax and eq are referred to the most stable conformer of each compound.

Table 2 Experimental and calculated selected ${ }^{1} \mathrm{H}$ NMR coupling constants $(\mathrm{Hz})$ of compounds 1,2 and 3

\begin{tabular}{lllllll}
\hline$J$ & 1 Exp. $^{a}$ & 1 Calcd & 2 Exp. $^{b}$ & 2 Calcd & 3 Exp. & 3 Calcd \\
\hline 6,5ax & 4.8 & 5.1 & 12.5 & 10.2 & 5.4 & 6.1 \\
6,5eq & 2.3 & 2.5 & 4.0 & 3.8 & 4.8 & 2.9 \\
5ax,5eq & 13.0 & 11.8 & 12.5 & 11.6 & 16.4 & 14.5 \\
5ax,4a & 13.0 & 11.1 & 12.5 & 10.4 & - & - \\
5eq,4a & 5.0 & 4.8 & 4.0 & 4.9 & - & - \\
5ax,4 & - & - & - & - & 1.8 & 2.2 \\
5eq,4 & - & - & - & - & 1.0 & 0.5 \\
4a,4ax & 16.0 & 13.4 & 16.0 & 13.5 & - & - \\
4a,4eq & 6.5 & 6.1 & 6.6 & 6.1 & - & - \\
4ax,4eq & 16.0 & 15.2 & 16.0 & 15.1 & - & - \\
${ }^{a} \mathrm{CDCl}_{3}, 298 \mathrm{~K} .^{b}{ }^{b} \mathrm{DMSO}_{6}, d_{6}, 308 \mathrm{~K} .^{c} \mathrm{CD}_{3} \mathrm{OD}, 298 \mathrm{~K}$. &
\end{tabular}


A<smiles>O=C1C[C@H]2C[C@H](C(=O)Nc3ccc(C(F)(F)F)cc3)c3ccccc3C2=NN1</smiles>

$1 \mathbf{a}$

B

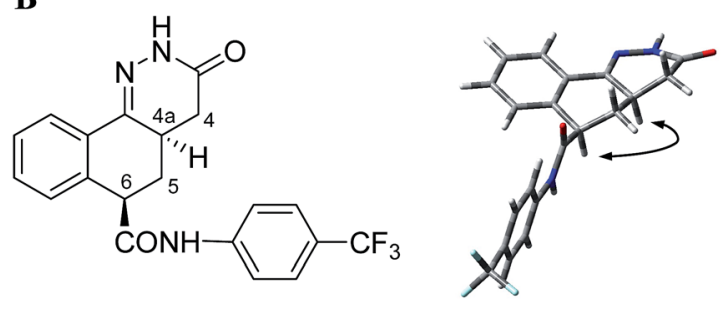

2a

Fig. 2 Chemical structures of compounds $1 \mathrm{a}$ and $2 \mathrm{a}$ and their corresponding preferred conformers. In the 3D-plot of $2 \mathrm{a}$ a double arrow highlights the proximity of $\mathrm{H}-6$ and $\mathrm{H}-4 a$ that explains the NOESY observed cross-peak.

optimized conformation of 1a-3a and averaged on the basis of the population percentages reported in Fig. 1.

NOESY experiments were also performed to confirm the $\mathbf{1}$ and 2 relative configurations. In fact for the $(6 R, 4 \mathrm{a} R) /(6 S, 4 \mathrm{a} S)$ configuration (Fig. 2B), a $2.6 \AA$ calculated distance between the C-6 and C-4a protons should account for a NOE contact. On the contrary, this should not be observable for the $(6 R, 4 \mathrm{a} S) /(6 S, 4 \mathrm{a} R)$ configuration (Fig. 2A) that showed a $3.8 \AA$ calculated distance. Actually, the comparison of the NOESY spectrum of 1 with the corresponding spectrum of 2 (see Fig. S1a and S1b, ESI $\dagger$ section) clearly showed an intense cross peak only between $\mathrm{H}-6$ and $\mathrm{H}-4 \mathrm{a}$ of 2 whose configuration was therefore ascertained to be $(6 R, 4 \mathrm{a} R) /(6 S, 4 \mathrm{a} S)$. Consequently 1 resulted to be unambiguously the $(6 R, 4 \mathrm{a} S) /(6 S, 4 \mathrm{a} R)$ isomer.

\section{Biological evaluation}

The STAT3 inhibitory activity was evaluated at $10 \mu \mathrm{M}$ and $50 \mu \mathrm{M}$ concentrations through a modified procedure of dual luciferase

Table 3 Dual luciferase assay results of compounds 1-3

\begin{tabular}{lll}
\hline Compound & $\%$ inh. $[10 \mu \mathrm{M}]$ & $\%$ inh. $[50 \mu \mathrm{M}]$ \\
\hline $\mathbf{1}$ & -3 & 6 \\
$(+)-\mathbf{1}$ & 9 & 35 \\
$(-)-\mathbf{1}$ & 9 & 14 \\
$\mathbf{2}$ & -6 & 3 \\
$(+)-\mathbf{2 a}$ & -8 & 12 \\
$(-)-2 b$ & 1 & 16 \\
$\mathbf{3}$ & 2 & 7 \\
$(+)-3 a$ & -2 & 24 \\
$(-)-3 \mathbf{b}$ & 2 & 30 \\
Cryptotanshinone & 78 & 85
\end{tabular}

assay $^{8}$ in human colorectal carcinoma cells HCT-116, characterized by uncontrolled expression of STAT3. The results are expressed as percentage inhibition after $24 \mathrm{~h}$ treatment with the test compounds and Cryptotanshinone ${ }^{9}$ (a natural phenanthrene-quinone derivative) which was used as the control (Table 3).

At the lower concentration none of the compounds showed any significant activity, while at $50 \mu \mathrm{M}$ concentration the best derivative was $(+) \mathbf{- 1}$, which however was less active than cryptotanshinone $(35 \%$ and $85 \%$, respectively). Also, the AlphaScreen-based assay ${ }^{10}$ did not reveal any strong interaction of the chimeras with the STAT3 SH2 domain (\% inhibition < 5), though they are incorporating the trifluoromethyl moiety that, in the case of MD77, cooperates in the binding to this domain.

\section{Conclusion}

During our studies, which aimed at the discovery of new potential STAT3 inhibitors, MD77 and I emerged as interesting molecules able to interfere in a different manner within the STAT3 pathway. These compounds were chemically merged leading to the chimeras $\mathbf{1}, \mathbf{2}$ and $\mathbf{3}$, by utilizing the moieties identified as important for the STAT3 activity.

The computational analysis on 1-3 revealed a very different conformational behavior of these compounds. In fact, while in $\mathbf{1}$ the trifluoromethylphenylamido chain almost exclusively prefers the pseudo-axial orientation, in 2 the opposite pseudoequatorial orientation is largely preferred. Compound 3 closely resembles 1 in the preference for the pseudo-axial orientation, though in a lesser percentage. This geometrical diversity encouraged the synthetic efforts, in particular the orientation of the $p$-trifluoromethylphenyl group with respect to the tricyclic moiety in 2 that seems comparable with the orientation of the same group with respect to the chlorophenyl oxadiazole moiety in MD77. Thus, the chimeras were synthesized and their racemate resolved.

Then, high field NMR spectroscopy and NOESY experiments were performed to give experimental support to the calculations and unambiguously assign the $\mathbf{1}$ and $\mathbf{2}$ relative configurations. The vicinal $J_{6,5 a x}$ coupling constant of 1 and 2 (Table 2) is in complete agreement with, respectively, an axial and equatorial orientation of the trifluoromethylphenylamido chain. The combination of the observed $J_{6,5}$ and $J_{5,4 \mathrm{a}}$ in the two diastereoisomers is compatible with the assignment of the $(6 R, 4 \mathrm{a} S) /$ $(6 \mathrm{~S}, 4 \mathrm{a} R)$ relative configuration to 1 and the $(6 R, 4 \mathrm{a} R) /(6 S, 4 \mathrm{a} S)$ to 2. Moreover, the intense cross-peak between $\mathrm{H}-6$ and $\mathrm{H}-4 \mathrm{a}$, observed only in the NOESY spectrum of 2, supports again its relative configuration, that makes these two hydrogens oriented on the same face of the molecule and relatively close $(2.6 \AA$ from the theoretical calculations) and not the diastereoisomeric $(6 R, 4 \mathrm{a} S) /(6 S, 4 \mathrm{a} R)$ configuration, that makes them trans-oriented and more spaced (3.8 $)$.

Finally, both the racemates and each single enantiomer of the new compounds were submitted to biological evaluation that did not bring about the identification of an advanced chemical lead, in spite of the presence in the molecules of moieties that have been shown suitable in other substrates. 
This indicates that the portions of MD77 not included in the chimera compounds seem to play a specific role that probably should not be neglected.

\section{Experimental}

General

Unless otherwise noted the materials were obtained from commercial suppliers (as starting reagents reported in Scheme 1) and used without purification. Commercial plates on aluminium-backed Silica Gel 60 plates $(0.2 \mathrm{~mm}$, Merck) were used for analytical TLC to follow the course of the reaction and to check the product purity. Silica gel 60 (Merck 40-63 $\mu \mathrm{M}$ ) was used for flash chromatography to purify intermediates and final compounds. The purity of final compounds was determined by HPLC analysis and was $\geq 95 \%$. Melting points were determined on a Buchi 510 capillary melting point apparatus and are uncorrected. ${ }^{1} \mathrm{H}$ NMR spectra were recorded on a Bruker AVANCE-500 spectrometer operating at $500.13 \mathrm{MHz}$; the chemical shifts are reported as $\delta$ (ppm) using the solvent as the internal standard. The enantiomeric separations of compounds $\mathbf{1}$ and $\mathbf{3}$ were performed by a chiral semi-preparative HPLC Chiralcel ODH $(5 \mu \mathrm{m}, 250 \times 4.6 \mathrm{~mm})$. The enantiomeric separation of compound 2 was performed by a chiral semi-preparative HPLC Chiralpak $\mathrm{AD}(5 \mu \mathrm{m}, 250 \times 4.6 \mathrm{~mm})$. Optical rotation values of the enantiomers were registered on a Perkin Elmer instrument (Mod 343) at $589 \mathrm{~nm}$ and $25{ }^{\circ} \mathrm{C}$. The structures of all compounds were consistent with their analytical and spectroscopic data.

4-Oxo-1,2,3,4-tetrahydronaphthalene-1-carboxylic acid 4. A mixture of $\alpha$-phenylglutaric anhydride $(0.5 \mathrm{~g}, 2.69 \mathrm{mmol})$ and 2 $\mathrm{g}$ of polyphosphoric acid was heated at $100-110{ }^{\circ} \mathrm{C}$ for $15 \mathrm{~min} .1$ $\mathrm{g}$ of polyphosphoric acid was added and the mixture was heated for $15 \mathrm{~min}$ at the same temperature. The solution appeared as a dense brown oil. The mixture was cooled with an ice bath, treated with water and extracted with ethyl acetate $(3 \times 2 \mathrm{~mL})$. The organic phase was firstly treated with $1 \mathrm{~N} \mathrm{NaOH}(2 \mathrm{~mL})$ and then the collected alkaline aqueous solution was acidified with $6 \mathrm{~N} \mathrm{HCl}(1 \mathrm{~mL})$ and extracted with ethyl acetate $(3 \times 1 \mathrm{~mL})$. The organic layer was dried over anhydrous $\mathrm{Na}_{2} \mathrm{SO}_{4}$ and evaporated under reduced pressure to afford 4 as a brown oil (90\% yield). ${ }^{1} \mathrm{H} \mathrm{NMR}\left(\mathrm{CDCl}_{3}\right) 2.38$ (dddd, $1 \mathrm{H}, J=13.8, J=12.0, J=4.8$ and $J$ $=4.8 \mathrm{~Hz}, \mathrm{CH}), 2.52(\mathrm{dddd}, 1 \mathrm{H}, J=13.8, J=4.8, J=4.8$ and $J=$ $4.8 \mathrm{~Hz}, \mathrm{CH}$ ), 2.65 (ddd, $1 \mathrm{H}, J=17.4, J=4.8$ and $J=4.8 \mathrm{~Hz}, \mathrm{CH}$ ), 2.92 (ddd, $1 \mathrm{H}, J=17.4, J=12.0$ and $J=4.8 \mathrm{~Hz}, \mathrm{CH}$ ), 3.99 (dd, $1 \mathrm{H}, J=4.8$ and $J=4.8 \mathrm{~Hz}, \mathrm{CH}), 7.37(\mathrm{dd}, 1 \mathrm{H}, J=7.50$ and $J=1.0$ $\mathrm{Hz}, \mathrm{ArH}$ ), 7.39 (ddd, $1 \mathrm{H}, J=7.50, J=7.50$ and $J=1.0 \mathrm{~Hz}, \mathrm{ArH}$ ), 7.53 (ddd, $1 \mathrm{H}, J=7.50, J=7.50$ and $J=1.5 \mathrm{~Hz}, \mathrm{ArH}$ ), 8.06 (dd, $1 \mathrm{H}, J=7.50$ and $J=1.5 \mathrm{~Hz}, \mathrm{ArH})$.

4-Oxo- $N$-(4-(trifluoromethyl)phenyl)-1,2,3,4 tetrahydronaphthalene-1-carboxamide 5 . To a solution of compound 4 (0.2 $\mathrm{g}, 1.05 \mathrm{mmol})$ in dichloromethane $(6 \mathrm{~mL})$ the coupling agent TBTU $(0.46 \mathrm{~g}, 1.42 \mathrm{mmol}), \mathrm{N}$-methylmorpholine (up to $\mathrm{pH}=7$ ) and 4-(trifluoromethyl)aniline $(0.4 \mathrm{~mL}, 3.21 \mathrm{mmol})$ were added. The resulting mixture was stirred at room temperature for $24 \mathrm{~h}$. The product was extracted with dichloromethane $(3 \times 2 \mathrm{~mL})$. The organic layer was washed first with $1 \mathrm{~N} \mathrm{HCl}(1 \times 2 \mathrm{~mL})$, then with a saturated solution of sodium hydrogencarbonate $(1 \times 2$ $\mathrm{mL})$ and finally with brine $(1 \times 2 \mathrm{~mL})$. The organic phase was dried over anhydrous $\mathrm{Na}_{2} \mathrm{SO}_{4}$, filtered and concentrated in vacuo. The residue was purified by flash chromatography (cyclohexane-ethyl acetate $7: 3$ ) to afford the intermediate 5 (62\% yield). ${ }^{1} \mathrm{H}$ NMR ( $\left.\mathrm{CD}_{3} \mathrm{OD}\right)$ 2.43-2.48 (m, 2H, $\mathrm{CH}_{2}$ ), 2.64 $(\mathrm{ddd}, 1 \mathrm{H}, J=17.5, J=6.0$ and $J=6.0 \mathrm{~Hz}, \mathrm{CH}), 2.96(\mathrm{ddd}, 1 \mathrm{H}, J=$ $17.5, J=14.0$ and $J=6.2 \mathrm{~Hz}, \mathrm{CH}), 4.13(\mathrm{dd}, 1 \mathrm{H}, J=5.7$ and $\mathrm{J}=$ $5.7 \mathrm{~Hz}, \mathrm{CH}), 7.36$ (dd, $1 \mathrm{H}, J=7.50$ and $J=1.0 \mathrm{~Hz}, \mathrm{ArH}), 7.42$ (ddd, $1 \mathrm{H}, J=7.50, J=7.50$ and $J=1.0 \mathrm{~Hz}, \mathrm{ArH}), 7.57$ (ddd, $1 \mathrm{H}, J$ $=7.50, J=7.50$ and $J=1.5 \mathrm{~Hz}, \mathrm{ArH}), 7.60(\mathrm{~d}, 2 \mathrm{H}, J=8.6 \mathrm{~Hz}$, $\mathrm{ArH}), 7.80$ (d, 2H, $J=8.6 \mathrm{~Hz}, \mathrm{ArH}), 8.03$ (dd, $1 \mathrm{H}, J=7.50$ and $J=1.5 \mathrm{~Hz}, \mathrm{ArH})$.

(Z)-2-(1-Oxo-4-(4-(trifluoromethyl)phenylcarbamoyl)-3,4-dihydronaphthalen-2(1H)-ylidene)acetic acid 6. A solution of $\mathrm{NaOH}$ $(0.26 \mathrm{~g}, 6.53 \mathrm{mmol})$ in water $(3.1 \mathrm{~mL})$ and ethanol $(1.63 \mathrm{~mL})$ was added dropwise to an ice-cooled solution of compound $5(0.44 \mathrm{~g}$, $1.33 \mathrm{mmol})$ and glyoxylic acid $(0.49 \mathrm{~g}, 5.27 \mathrm{mmol})$ in water $(1.8$ $\mathrm{mL}$ ). This solution was stirred at room temperature for $1 \mathrm{~h}$ and then ethanol was removed under reduced pressure. The obtained aqueous mixture was acidified with $6 \mathrm{~N} \mathrm{HCl}$ and the precipitate was filtered, washed with $6 \mathrm{~N} \mathrm{HCl}(1 \times 1 \mathrm{~mL})$ and dried to give a yellow residue. The crude solid was purified by flash chromatography (dichloromethane-methanol 9:1 with $0.02 \mathrm{~mL}$ of acetic acid) to provide compound 6 (47\% yield). ${ }^{1} \mathrm{H}$ NMR ( $\left.\mathrm{CD}_{3} \mathrm{OD}\right) 3.16$ (ddd, $1 \mathrm{H}, J=16.6, J=4.8$ and $J=2.7 \mathrm{~Hz}$, $\mathrm{CH}$ ), $4.13(\mathrm{dd}, 1 \mathrm{H}, J=16.6$ and $J=4.0 \mathrm{~Hz}, \mathrm{CH}), 4.22$ (dd, $1 \mathrm{H}$, $J=4.8$ and $J=4.0 \mathrm{~Hz}, \mathrm{CH}), 6.91(\mathrm{br} \mathrm{s}, 1 \mathrm{H},=\mathrm{CH}), 7.46(\mathrm{dd}, 1 \mathrm{H}$, $J=7.50$ and $J=1.0 \mathrm{~Hz}, \mathrm{ArH}), 7.48(\mathrm{ddd}, 1 \mathrm{H}, J=7.80, J=7.50$ and $J=1.1 \mathrm{~Hz}, \mathrm{ArH}), 7.56$ (d, 2H, $J=8.5 \mathrm{~Hz}, \mathrm{ArH}), 7.61(\mathrm{ddd}, 1 \mathrm{H}, J=$ $7.50, J=7.50$ and $J=1.4 \mathrm{~Hz}, \mathrm{ArH}), 7.70$ (d, 2H, $J=8.5 \mathrm{~Hz}, \mathrm{ArH})$, $8.07(\mathrm{dd}, 1 \mathrm{H}, J=7.8$ and $J=1.4 \mathrm{~Hz}, \mathrm{ArH})$.

2-(1-Oxo-4-(4-(trifluoromethyl)phenylcarbamoyl)-1,2,3,4-tetrahydronaphthalen-2-yl)acetic acids 7, 8. Compound $6(0.173 \mathrm{~g}$, $0.44 \mathrm{mmol}$ ) and zinc dust $(0.34 \mathrm{~g}, 0.52 \mathrm{mmol})$ in acetic acid (4.95 $\mathrm{mL})$ and water $(1.24 \mathrm{~mL})$ were heated at $60{ }^{\circ} \mathrm{C}$ for $20 \mathrm{~min}$. Then the reaction mixture was cooled to room temperature and the amount of zinc was filtered off. The mixture of diastereoisomers 7 and 8 (91\% yield) was extracted with ethyl acetate $(3 \times 2 \mathrm{~mL})$; the organic layer was dried over anhydrous $\mathrm{Na}_{2} \mathrm{SO}_{4}$ and the solvent was evaporated under reduced pressure. The mixture was not separated and used without further purification. ${ }^{1} \mathrm{H}$ NMR $\left(\mathrm{CD}_{3} \mathrm{OD}\right) 2.36$ (ddd, $1 \mathrm{H}, J=12.7, J=12.7$ and $J=12.7 \mathrm{~Hz}, 1 \mathrm{H}$, $\mathrm{CH}$ ), 2.47 (ddd, $1 \mathrm{H}, J=12.7, J=4.3$ and $J=4.3 \mathrm{~Hz}, 1 \mathrm{H}, \mathrm{CH}$ ), 2.51 (dd, $1 \mathrm{H}, J=16.8$ and $J=6.4 \mathrm{~Hz}, \mathrm{CH}$ ), 2.95 (dd, $1 \mathrm{H}, J=16.8$ and $J$ $=5.7 \mathrm{~Hz}, \mathrm{CH}), 3.13(\mathrm{dddd}, 1 \mathrm{H}, J=12.7, J=5.7, J=6.4$ and $J=4.3$ $\mathrm{Hz}, \mathrm{CH}), 4.27$ (dd, $1 \mathrm{H}, J=12.0$ and $J=4.3 \mathrm{~Hz}, \mathrm{CH}), 7.38-7.43(\mathrm{~m}$, $2 \mathrm{H}, \mathrm{ArH}$ ), 7.57 (ddd, $1 \mathrm{H}, J=7.50, J=7.50$ and $J=1.5 \mathrm{~Hz}, \mathrm{ArH}$ ), 7.64 (d, 2H, $J=8.5 \mathrm{~Hz}, \operatorname{ArH}), 7.86$ (d, 2H, $J=8.5 \mathrm{~Hz}, \operatorname{ArH}), 8.02$ (dd, $1 \mathrm{H}, J=7.8$ and $J=1.5 \mathrm{~Hz}, \mathrm{ArH}$ ).

3-Oxo- $N$-(4-(trifluoromethyl)phenyl)-2,3,4,4a,5,6-hexahydrobenzo $[h]$ cinnoline-6-carboxamide 1,2 . To a mixture of diastereoisomers 7 and $8(0.15 \mathrm{~g}, 0.38 \mathrm{mmol})$ in ethanol $(4 \mathrm{~mL})$, hydrazine monohydrate $(0.09 \mathrm{~mL}, 1.93 \mathrm{mmol})$ was added dropwise and the obtained yellow solution was refluxed for $2 \mathrm{~h}$. After evaporation of the solvent, the reaction mixture was extracted with ethyl acetate $(5 \times 1 \mathrm{~mL})$. The organic layer was 
dried over anhydrous $\mathrm{Na}_{2} \mathrm{SO}_{4}$, filtered and the solvent was evaporated under reduced pressure. The two diastereoisomers 1 and 2 (64\% yield; diastereomeric ratio $1: 2=8: 2$ ) were separated by flash chromatography (dichloromethane-methanol 9.8 : 0.2). Compound 1 (yellow solid): $\mathrm{mp} 230.2-232.4{ }^{\circ} \mathrm{C} .{ }^{1} \mathrm{H}$ NMR $\left(\mathrm{CDCl}_{3}\right) 1.89$ (ddd, $1 \mathrm{H}, J=13.0, J=13.0$ and $J=4.8 \mathrm{~Hz}$, $\mathrm{CH}), 2.23(\mathrm{dd}, 1 \mathrm{H}, J=16.0$ and $J=16.0 \mathrm{~Hz}, \mathrm{CH}), 2.71(\mathrm{dd}, 1 \mathrm{H}, J$ $=16.0$ and $J=6.5 \mathrm{~Hz}, \mathrm{CH}), 2.84(\mathrm{ddd}, 1 \mathrm{H}, J=13.0, J=5.0$ and $J$ $=2.3 \mathrm{~Hz}, \mathrm{CH}), 3.00(\mathrm{dddd}, J=16.0, J=13.0, J=6.5$ and $J=5.0$ $\mathrm{Hz}, 1 \mathrm{H}, \mathrm{CH}$ ), 3.99 (dd, $1 \mathrm{H}, J=4.8$ and $J=2.3 \mathrm{~Hz}, \mathrm{CH}$ ), 7.10 (br s, $1 \mathrm{H}, \mathrm{NH}), 7.34(\mathrm{dd}, 1 \mathrm{H}, J=7.0$ and $J=1.9 \mathrm{~Hz}, \mathrm{ArH}), 7.42-7.52(\mathrm{~m}$, $6 \mathrm{H}, \mathrm{ArH}$ ), 8.23 (dd, $1 \mathrm{H}, J=7.4$ and $J=1.9 \mathrm{~Hz}, \mathrm{ArH}$ ), 8.52 (br s, $1 \mathrm{H}, \mathrm{NH})$. The enantiomeric separation of 1 was performed by a chiral semi-preparative HPLC: Chiralcel ODH $(5 \mu \mathrm{m}, 250 \times 4.6$ $\mathrm{mm}$ ), hexane-ethanol (85: 15), $0.8 \mathrm{~mL} \mathrm{~min}^{-1}$, UV $254 \mathrm{~nm} ; t_{\mathrm{R}}(1)$ $=10.564 \min (49.92 \%) .(+)-1:[\alpha]_{\mathrm{D}}^{25}=+16\left(c 0.0016, \mathrm{CH}_{3} \mathrm{OH}\right)$; $t_{\mathrm{R}}(2)=12.503 \min (50.08 \%)(-)-1:[\alpha]_{\mathrm{D}}^{25}=-16(c \quad 0.0016$, $\mathrm{CH}_{3} \mathrm{OH}$ ). Compound 2 (white solid): $\mathrm{mp}\left(277.1-279.8{ }^{\circ} \mathrm{C}\right) .{ }^{1} \mathrm{H}$ NMR (DMSO- $d_{6}$ ) 1.95 (ddd, $1 \mathrm{H}, J=12.5, J=12.5$ and $J=12.5$ $\mathrm{Hz}, 1 \mathrm{H}, \mathrm{CH}$ ), 2.29 (ddd, $1 \mathrm{H}, J=12.5, J=4.0$ and $J=4.0 \mathrm{~Hz}, \mathrm{CH}$ ), $2.36(\mathrm{dd}, 1 \mathrm{H}, J=16.0$ and $J=16.0 \mathrm{~Hz}, \mathrm{CH}), 2.52(\mathrm{dd}, 1 \mathrm{H}, J=16.0$ and $J=6.6 \mathrm{~Hz}, \mathrm{CH}), 2.98(\mathrm{dddd}, J=16.0, J=12.5, J=6.6$ and $J=$ $4.0 \mathrm{~Hz}, 1 \mathrm{H}, \mathrm{CH}), 3.97$ (dd, $1 \mathrm{H}, J=12.5$ and $J=4.0 \mathrm{~Hz}, \mathrm{CH}), 7.16$ (dd, $1 \mathrm{H}, J=7.20$ and $J=1.0 \mathrm{~Hz}, \mathrm{ArH}), 7.34(\mathrm{ddd}, 1 \mathrm{H}, J=7.80, J=$ 7.20 and $J=1.0 \mathrm{~Hz}, \mathrm{ArH}$ ), 7.37 (ddd, $1 \mathrm{H}, J=7.20, J=7.20$ and $J=1.8 \mathrm{~Hz}, \mathrm{ArH}), 7.73$ (d, 2H, $J=8.5 \mathrm{~Hz}, \mathrm{ArH}), 7.92$ (d, 2H, $J=8.5$ $\mathrm{Hz}, \mathrm{ArH}), 8.08$ (dd, $1 \mathrm{H}, J=7.8$ and $J=1.8 \mathrm{~Hz}, \mathrm{ArH})$. The enantiomeric separation of 2 was performed by a chiral semipreparative HPLC: Chiralpak $\mathrm{AD}(5 \mu \mathrm{m}, 250 \times 4.6 \mathrm{~mm})$, hexane-

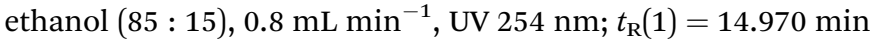
(49.68\%). 2a: $[\alpha]_{\mathrm{D}}^{25}=+264(c 0.0012, \mathrm{DMSO}) ; t_{\mathrm{R}}(2)=19.781 \mathrm{~min}$ (50.32\%). 2b: $[\alpha]_{\mathrm{D}}^{25}=-287$ (c 0.0012, DMSO).

3-Oxo- $\mathrm{N}$-(4-(trifluoromethyl)phenyl)-2,3,5,6-tetrahydro-benzo[h]cinnoline-6-carboxamide 3. A mixture of compound 1 ( $0.050 \mathrm{~g}, 0.13$ $\mathrm{mmol})$, sodium $m$-nitro-benzenesulfonate $(0.029 \mathrm{~g}, 0.13 \mathrm{mmol})$, and $\mathrm{NaOH}(0,021 \mathrm{~g}, 0.52 \mathrm{mmol})$ in water $(1 \mathrm{~mL})$ was refluxed for 30 min. After cooling, the reaction mixture was extracted with ethyl acetate $(3 \times 1 \mathrm{~mL})$ and the organic layer was dried over anhydrous $\mathrm{Na}_{2} \mathrm{SO}_{4}$, filtered and the solvent was evaporated under reduced pressure. The obtained residue was purified by flash chromatography (dichloromethane-methanol $9.7: 0.3$ ) to afford 3 as a yellow solid (85\% yield). Sublimation was performed at $333.4-338.7^{\circ} \mathrm{C} .{ }^{1} \mathrm{H}$ $\operatorname{NMR}\left(\mathrm{CD}_{3} \mathrm{OD}\right) 3.20$ (ddd, $1 \mathrm{H}, J=16.4, J=5.4$ and $\left.J=1.8 \mathrm{~Hz}, \mathrm{CH}\right)$, 3.26 (ddd, $1 \mathrm{H}, J=16.4, J=4.8$ and $J=1.0 \mathrm{~Hz}, \mathrm{CH}$ ), 4.09 (dd, $J=5.4$ and $J=4.8 \mathrm{~Hz}, 1 \mathrm{H}, \mathrm{CH}), 6.83(\mathrm{br} \mathrm{s}, 1 \mathrm{H}, \mathrm{CH}), 7.38-7.44(\mathrm{~m}, 3 \mathrm{H}, \mathrm{ArH})$, $7.57(\mathrm{~d}, 2 \mathrm{H}, J=8.5 \mathrm{~Hz}, \mathrm{ArH}), 7.71$ (d, 2H, $J=8.5 \mathrm{~Hz}, \mathrm{ArH}), 8.14(\mathrm{~m}$, $1 \mathrm{H}, \mathrm{ArH})$. The enantiomeric separation of compound 3 was performed by a chiral semi-preparative HPLC: Chiralcel ODH (5 $\mu \mathrm{m}$, $250 \times 4.6 \mathrm{~mm}$ ), hexane-ethanol (80:20), $0.8 \mathrm{~mL} \mathrm{~min}^{-1}$, UV 254 $\mathrm{nm} ; t_{\mathrm{R}}(1)=8.244 \min (50.3 \%) 3 \mathbf{b}:[\alpha]_{\mathrm{D}}^{25}=-210\left(c 0.0016, \mathrm{CH}_{3} \mathrm{OH}\right)$; $t_{\mathrm{R}}(2)=8.968 \min (49.7 \%) 3 \mathrm{a}:[\alpha]_{\mathrm{D}}^{25}=+194\left(c 0.0016, \mathrm{CH}_{3} \mathrm{OH}\right)$.

\section{NMR spectroscopy}

NMR spectra were recorded at $298 \mathrm{~K}$ or $308 \mathrm{~K}$ (DMSO- $d_{6}$ spectra) with a Bruker AVANCE-500 spectrometer operating at 500.13 $\mathrm{MHz}$ for ${ }^{1} \mathrm{H}$, using a $5 \mathrm{~mm}$ single pulsed field gradient ( $z$-PFG) broadband reverse probe. Chemical shifts are reported on the $\delta(\mathrm{ppm})$ scale and are relative to chloroform (7.24 ppm), DMSO (2.51 ppm) or methanol (3.30 ppm) signals. Compounds (about $5 \mathrm{mg}$ ) were dissolved in $0.5 \mathrm{~mL}$ of $\mathrm{CDCl}_{3}(1)$, DMSO- $d_{6}(2)$ or $\mathrm{CD}_{3} \mathrm{OD}$ (3) under $\mathrm{N}_{2}$, and their assignments were given by a combination of $1 \mathrm{D}$ and 2D COSY experiments, using standard Bruker pulse programs. Z-PFGs were used to obtain ${ }^{1} \mathrm{H}-{ }^{1} \mathrm{H}$ COSY spectra. The pulse width was $7.50 \mu \mathrm{s}\left(90^{\circ}\right)$ for ${ }^{1} \mathrm{H}$. Typically 32768 data points were collected for one-dimensional spectra. The spectral width was $11.45 \mathrm{ppm}(5733 \mathrm{~Hz})$ for ${ }^{1} \mathrm{H}$ NMR (digital resolution: $0.17 \mathrm{~Hz}$ per point). 2D experimental parameters were as follows. For ${ }^{1} \mathrm{H}-{ }^{1} \mathrm{H}$ correlations: relaxation delay $2.0 \mathrm{~s}$, $1024 \times 1024$ data point matrices (512 experiments to 1024 zero filling in $\mathrm{F}_{1}, 1024$ in $\mathrm{F}_{2}$ ), 2 or 16 transients in each experiment for COSY and NOESY respectively, spectral width $11.15 \mathrm{ppm}$ $(5580.37 \mathrm{~Hz})$. The NOESY spectra were generated with a mixing time of $1.0 \mathrm{~s}$ and acquired in the TPPI mode. There were no significant differences in the results obtained at different mixing times (0.5-1.5 s). All 2D spectra were processed with the Bruker software package.

\section{Computational methods}

All calculations were performed using the Gaussian09 program package ${ }^{6}$ at the B3LYP/6-311+G(d,p) level. Theoretical values of the $[\alpha]_{\mathrm{D}}$ were obtained at the same level of theory specifying appropriate keywords (polar and cphf) into the Gaussian input. GIAO NMR ${ }^{11}$ calculations were carried out at the B3LYP/6$311+\mathrm{G}(\mathrm{d}, \mathrm{p})$ level. The coupling constants were calculated with Ramsey's nonrelativistic approach ${ }^{\mathbf{1 2}}$ and were weight-averaged on the basis of the population percentages.

\section{Biological assays}

Dual luciferase assay. Cell culture: the cancer cell lines were obtained from American Type Culture Collection. Human breast cancer cell lines (MDA-MB-468, MDA-MB-231) and human colon cancer cell line (SW620) were maintained in RPMI 1640 (Gibco/BRL). Human colon cancer cell line (HCT-116) was maintained in McCoy's 5A (Gibco/BRL). All culture media were supplemented with $10 \%$ heat-inactivated fetal bovine serum (Gibco/BRL). Cell cultures were maintained at $37{ }^{\circ} \mathrm{C}$ under a humidified atmosphere of $5 \% \mathrm{CO}_{2}$ in an incubator. Transient transfection and dual-luciferase assays: ${ }^{8}$ HCT-116 cells were seeded at a density of $10 \times 10^{5}$ cells in $100 \mathrm{~mm}^{2}$ culture plate. The cells were co-transfected with pSTAT3-TA-Luc $(27 \mu \mathrm{g}$ per plate) and internal control plasmid pRL-TK $(9 \mu \mathrm{g}$ per plate) containing the Renilla luciferase gene. All plasmids used in this experiment were purchased from Promega. The transfection was carried out using TransFectin (Bio-Rad) according to the manufacturer's protocol. After $5 \mathrm{~h}$ of transfection, the cells were trypsinized and seeded onto sterilized black bottom 96-well plates at a density of $1 \times 10^{4}$ cells per well. On the following day, cells were treated with test compounds and incubated for $24 \mathrm{~h}$. Firefly and Renilla luciferase activities were measured using a dual-light reporter gene assay kit (Promega) on Wallac Victor2 (Perkin-Elmer, Inc., Wellesley, MA). Renilla luciferase activity was determined to calibrate the transfection efficiency and 
cytotoxicity of chemicals. Relative STAT3 activity was calculated by dividing the firefly luciferase activity with Renilla luciferase activity in each transfection experiment. The values of STAT3 inhibitory activity were the means of 3 experiments and the maximum deviation from the mean was less than $10 \%$.

AlphaScreen-based Assay. AlphaScreen ${ }^{\circledR}$ is a bead-based nonradioactive assay system for detecting biomolecular interactions in a microtiter plate format. Binding of biological partners brings donor and acceptor beads into close proximity and as result, a fluorescent signal between 520 and $620 \mathrm{~nm}$ is produced. The AlphaScreen-based assays ${ }^{\mathbf{1 0}}$ were performed in a final reaction volume of $25 \mu \mathrm{L}$ of the assay buffer containing 10 $\mathrm{mM}$ HEPES-NaOH (pH 7.4), $50 \mathrm{mM} \mathrm{NaCl}, 1 \mathrm{mM}$ EDTA (pH 8.0), $0.1 \% \mathrm{NP}-40$, and $10 \mathrm{ng} \mu \mathrm{L}^{-1} \mathrm{BSA}$ in a 96-well microtiter plate at $25{ }^{\circ} \mathrm{C}$. Phospho-Tyr (pTyr) peptide probes used in this study were 5-carboxyfluorescein (FITC)-GPYLPQTV for STAT3, FITCGPYDKPHVL for STAT1, and FITC-PSPYVNVQN for Grb2. Firstly, $75 \mathrm{nM}$ of each $\mathrm{SH} 2$-containing protein was incubated with the test compound for $15 \mathrm{~min}$. Each protein sample was then incubated for $90 \mathrm{~min}$ with $50 \mathrm{nM}$ of its corresponding FITC-pTyr peptide, and mixed with streptavidin coated donor beads and anti-FITC acceptor beads simultaneously before detection at $570 \mathrm{~nm}$ using EnVison Xcite (PerkinElmer).

\section{Acknowledgements}

The authors acknowledge the Universities of Milan and Pavia, and CINECA for the allocation of computer time. This study was supported by funds from PRIN 2010-2011. B. M. Kwon was supported by the Bio \& Medical Technology Development Program (2012M3A9C404877).

\section{Notes and references}

1 J. E. Darnell Jr, Science, 1997, 277, 1630-1635.

2 D. Masciocchi, A. Gelain, S. Villa, F. Meneghetti and D. Barlocco, Future Med. Chem., 2011, 3, 367-397.

3 D. Masciocchi, S. Villa, F. Meneghetti, A. Pedretti, L. Legnani, L. Toma, B.-M. Kwon, S. Nakano, A. Asai and A. Gelain, MedChemComm, 2012, 3, 592-599.

4 D. Masciocchi, A. Gelain, F. Meneghetti, A. Pedretti, G. Celentano, D. Barlocco, L. Legnani, L. Toma, B.-M. Kwon, A. Asai and S. Villa, MedChemComm, 2013, 4, 1181-1188.
5 L. Toma, G. Cignarella, D. Barlocco and F. Ronchetti, J. Med. Chem., 1990, 33, 1591-1594.

6 M. J. Frisch, G. W. Trucks, H. B. Schlegel, G. E. Scuseria, M. A. Robb, J. R. Cheeseman, G. Scalmani, V. Barone, B. Mennucci, G. A. Petersson, H. NakatsuJi, M. Caricato, X. Li, H. P. Hratchian, A. F. Izmaylov, J. Bloino, G. Zheng, J. L. Sonnenberg, M. Hada, M. Ehara, K. Toyota, R. Fukuda, J. Hasegawa, M. Ishida, T. NakaJima, Y. Honda, O. Kitao, H. Nakai, T. Vreven, J. A. Montgomery Jr, J. E. Peralta, F. Ogliaro, M. Bearpark, J. J. Heyd, E. Brothers, K. N. Kudin, V. N. Staroverov, R. Kobayashi, J. Normand, K. Raghavachari, A. Rendell, J. C. Burant, S. S. Iyengar, J. Tomasi, M. Cossi, N. Rega, J. M. Millam, M. Klene, J. E. Knox, J. B. Cross, V. Bakken, C. Adamo, J. Jaramillo, R. Gomperts, R. E. Stratmann, O. Yazyev, A. J. Austin, R. Cammi, C. Pomelli, J. W. Ochterski, R. L. Martin, K. Morokuma, V. G. Zakrzewski, G. A. Voth, P. Salvador, J. J. Dannenberg, S. Dapprich, A. D. Daniels, Ö. Farkas, J. B. Foresman, J. V. Ortiz, J. Cioslowski and D. J. Fox, Gaussian 09, Revision A.02, Gaussian, Inc., Wallingford CT, 2009.

7 (a) P. J. Stephens, F. J. Devlin, J. R. Cheeseman, M. J. Frisch and C. Rosini, Org. Lett., 2002, 4, 4595-4598; (b) B. Mennucci, J. Tomasi, R. Cammi, J. R. Cheeseman, M. J. Frisch, F. J. Devlin, S. Gabriel and P. J. Stephens, J. Phys. Chem. A, 2002, 106, 6102-6113; (c) E. Giorgio, M. RoJe, K. Tanaka, Z. Hamersak, V. Sunjic, K. Nakanishi, C. Rosini and N. Berova, J. Org. Chem., 2005, 70, 6557-6563; (d) A. C. Petrovic, J. He, P. L. Polavarapu, L. S. Xiao and D. W. Armstrong, Org. Biomol. Chem., 2005, 3, 1977-1981; (e) M. Zappalà, G. Postorino, N. Micale, S. Caccamese, N. Parrinello, G. Grazioso, G. Roda, F. S. Menniti, G. De Sarro and S. Grasso, J. Med. Chem., 2006, 49, 575-581.

8 B. A. Sherf, S. L. Navarro, R. R. Hannah and K. V. Wood, Promega Notes Mag., 1996, 57, 2-8.

9 D.-S. Shin, H.-N. Kim, K. D. Shin, Y. J. Yoon, S.-J. Kim, D. C. Han and B.-M. Kwon, Cancer Res., 2009, 69, 193-202.

10 Y. Uehara, M. Mochizuki, K. Matsuno, T. Haino and A. Asai, Biochem. Biophys. Res. Commun., 2009, 380, 627-631.

11 (a) K. Wolinski, F. James, J. F. Hinton and P. Pulay, J. Am. Chem. Soc., 1990, 112, 8251-8260; (b) R. Ditchfield, Mol. Phys., 1974, 27, 789-807.

12 T. Helgaker, M. Watson and N. C. Handy, J. Chem. Phys., 2000, 113, 9402-9409. 